\title{
VALUATION AND UNDERPRICING OF TURKISH IPOs *
}

\author{
Lokman TUTUNCU $\mathbb{D}^{*}$ \\ Faculty of Economics and Management, Bulent Ecevit University, Zonguldak, Turkey
}

Received 24 November 2018; accepted 03 January 2020

\begin{abstract}
This study utilizes prospectuses and supplementary valuation reports to investigate the relationship between underwriters' valuation and underpricing in 113 firms going public on Borsa Istanbul. It argues that underwriter discretion in the valuation is crucial to underpricing in the Turkish market, where fixed price is the dominant method of offering and retail investor allocation is large. Building on the overpricing theories, the study hypothesizes and finds that optimistic valuation bias is a significant determinant of underwriter discounts, and underwriter discounts are negatively associated with initial returns. One standard deviation increase in deliberate discounts is associated with a $30.4 \%$ reduction in underpricing. The median underwriter discount in the sample is $21 \%$, while the median market-adjusted initial return is a small $1.45 \%$, indicating that discounts might not be designed to induce underpricing and reward investors. Book-built offerings are overvalued and overdiscounted; however, not underpriced, contrasting the information extraction view.
\end{abstract}

Keywords: initial public offering (IPO), valuation, underpricing, underwriter discount, bookbuilding, fixed price, Turkey.

JEL Classification: G14, G30, G32.

\section{Introduction}

This study investigates valuation of initial public offerings (IPO) and its relation with the well-documented underpricing. It takes advantage of the disclosure regulations for issuers to obtain valuation reports and examine the relation between price-setting process and underpricing. Present theories focus on the asymmetric information between issuers and investors (Rock, 1986; Allen \& Faulhaber, 1989), discretionary allocation power of underwriters (Benveniste \& Spindt, 1989) and optimistic investor sentiment (Derrien, 2005; Ljungqvist et al., 2006) to explain underpricing. The Turkish IPO market presents an interesting case to explore and test the predictions of these theories due to the prevalent use of fixed price of-

\footnotetext{
- A previous version of the paper titled 'Valuation of Turkish IPOs' was presented at the 2018 International Conference on Empirical Economics and Social Sciences, Bandirma, Turkey.
}

*Corresponding author. E-mail: lokman.t@beun.edu.tr 
ferings and more dominant position of individual investors, in contrast to the US and other developed markets where bookbuilding method of offering and institutional investors tend to dominate the new issue market. Consequently, the offer price is often set prior to consultation with institutional investors and extracting their private information. In this setting, issuer and investor sentiment becomes more important to initial returns due to highly asymmetric informational environment and lack of mutual deliberations over the value of the issue. In the Benveniste and Spindt (1989) framework, underpricing is associated with the bookbuilding as a private information extraction mechanism. Rock's (1986) model envisions price discounts as a compensation strategy to keep uninformed investors in the market. Chowdhry and Sherman (1996a) posit that favouring individual investors over institutional investors may mitigate Rock's (1986) adverse selection problem and the need to compensate them, enabling underwriters to price the issue at higher levels. In a similar vein, Derrien (2005) proposes that underwriters may overvalue the issue if uninformed investors are optimistic. Thus, underwriters may not need to underprice the offering to induce institutional investors to reveal their private information, as optimistic investors will provide sufficient demand at a high price level. The relatively high proportion of retail investors and the dominant use of fixed price mechanism in the Turkish market provides a unique opportunity to capture underwriters' discretion in valuation and enhance the understanding of underpricing.

Underpricing theories explicitly or implicitly associate initial returns with underwriter discounts, which are implemented on the sole purpose of providing positive initial returns to investors. However, to maintain this argument one needs to be informed about the valuation procedure, which cannot be observed in the US market due to prohibitive disclosure regulations (Bradley et al., 2003). For this reason, it is common for researchers to use a matched peer multiples procedure to evaluate value estimations (Kim \& Ritter, 1999; Purnanandam \& Swaminathan, 2004; Colaco et al., 2017; Haggard \& Xi, 2017). In the European markets, recent regulations allowed several studies to investigate IPO valuation directly from the information disclosed in prospectuses. Roosenboom $(2007,2012)$ explain the valuation methodology employed by French underwriters. Deloof et al. (2009) investigate valuation models used by Belgian investment banks. Paleari et al. (2014) and Vismara et al. (2015) study valuation of French, German and Italian IPOs. Similar to these European markets, Turkish IPO prospectuses contain details of the valuation methodology or they are supplemented with valuation reports, which are published on the Public Disclosure Platform (KAP) and investor relations section of the issuer websites. The disclosure of valuation information prior to going public is regulated by the Capital Markets Board (SPK) (2013a), allowing access to related IPO filings to see how underwriters determine the offer price. The valuation reports include percentage underwriter discounts, a key element of the underpricing theories of Rock (1986) and Benveniste and Spindt (1989), enabling a direct test of the relationship between discounts and initial returns.

Roosenboom (2012) argues that underwriters inflate the value of the firm to advertise larger deliberate discounts as a strategy to attract investors, where discounting serves to underprice the issue. If discounts are offered on the basis of providing positive initial returns to investors, and percentage discounts advertised in the valuation reports are taken at the face value, the discounts and underpricing should be proportional. The statement; however, implies a correlation with overvaluation if the relation is not proportional. In fact, the issue 
could be overvalued and underpriced at the same time if uninformed traders possess optimistic sentiment and pay a higher price relative to the intrinsic value of the offering (Derrien, 2005). In the spirit of Derrien (2005), the study argues that underwriters would apply deliberate discounts in a manner that offered discount does not fully offset the optimistic bias in the estimate. The underwriter discretion in the discounting may be used to overprice the issue while appearing conservative at the same time. The incentive to overprice the issue might be further corroborated by the mitigated adverse selection problem due to the large individual investor allocation in the new issue market (Chowdhry \& Sherman, 1996a). The overpricing; however, may lead to lower initial returns because of the inherent optimistic bias in the final offer price. Hundtofte and Torstila (2018) propose an anchoring hypothesis, where undervalued offerings are associated with larger and overvalued offerings are associated with lower aftermarket returns, returns adjusted as the price reverts to its true value. Therefore, the study predicts that underwriter discounts are positively associated with the valuation bias and negatively associated with initial returns. This line of reasoning runs counter to the underpricing theories, as they envision discounting as a strategy to induce positive initial returns. It is; however, consistent with the optimistic investor sentiment (Derrien, 2005) and anchoring hypotheses (Hundtofte \& Torstila, 2018).

The study consists of 113 firms going public on Borsa Istanbul between April 2010 and September 2018. Main findings contrast with Rock's (1986) adverse selection and Benveniste and Spindt's (1989) information extraction models of underpricing, while they support overpricing theories. Specifically, they show that market multiples (MM) and discounted cash flows (DCF) are the two most popular valuation techniques, accounting for $87.22 \%$ of the total fair value estimates. The valuation procedure involves large optimistic estimation bias, and the median IPO value estimate is discounted by $21 \%$ to set the final offer price. However, the valuation bias is not discounted away as underwriter discounts are associated with larger bias and lower initial returns. One standard deviation increase in deliberate discounts is associated with a $30.4 \%$ reduction in market-adjusted initial returns. The median initial return is a mere $0.8 \%$ and median market-adjusted initial return is $1.45 \%$. The bookbuilding method is associated with more biased and less accurate value estimates, and book-built offerings are subject to larger discounts; however, they are not more underpriced than fixed price offerings. Retail and institutional investors subscribe more to underpriced offerings and less to overpriced offerings, suggesting that they do not suffer from the winner's curse. Both retail and institutional investor demand density appear to play a positive role in the initial returns. Overall, the results are consistent with Chowdhry and Sherman (1996a), Derrien (2005), and Ljungqvist et al. (2006) overpricing theories.

This study makes two main contributions to the finance literature. First, it contributes to the pricing literature by showing that underwriter discounts are correlated with overvaluation bias, in contrast to the prevalent assumption that discounts are used to induce underpricing. Second, it contributes to the IPO literature by providing the first comparison of pre-issue valuation in fixed-price and book-built offerings. Prior comparative studies focus on the underpricing, ignoring the underwriter discretion in valuation. This study complements existing valuation evidence from European markets and underpricing evidence in general. It might be of interest to the investors, regulators, and other players in IPO markets. 
The remainder of the study is organized as follows: Section 1 reviews the literature and develops hypotheses, Section 2 discusses data, valuation techniques and descriptive statistics. Section 3 presents tests of valuation and underpricing. Last Section concludes the study.

\section{Literature review and hypothesis development}

Valuation of IPOs is an intriguing question due to the widespread underpricing documented in the world markets. Existing theoretical and empirical literature predicts an important connection between valuation and initial returns, which manifests itself in the form of underwriter discretion in valuation and subsequent effects on the aftermarket returns. Theorists argue that investment banks possess incentives to suppress the value maximization objective in exchange for investor interest and market balance. To do that, they offer price discounts to prevent a winner's curse to uninformed investors (Rock, 1986) and to impress and extract private information of institutional investors (Benveniste \& Spindt, 1989; Shiller, 1990), effectively underpricing the issue. Other explanations include underpricing to signal issue quality (Allen \& Faulhaber, 1989) and to avoid litigation (Tinic, 1988). In contrast to these underpricing models, other works emphasize investor sentiment and overpricing. Derrien (2005) proposes that aftermarket price of the issue depends on the intrinsic value of the firm, as well as uninformed investors' optimistic sentiment, who might be exploited to pay higher prices relative to the intrinsic value, overvaluing and underpricing the issue at the same time. After all, IPO timing theories suggest that issuers time their offerings to coincide with periods of optimism (Loughran et al., 1994; Baker \& Wurgler, 2000). Similarly, Ljungqvist et al. (2006) posit that underpricing arises as compensation to regular institutional investors, who take advantage of the optimistic sentiment of retail traders in the aftermarket to sell their acquisitions from the issue. The expropriated value from retail investors is consequently reflected in the higher offer price.

Underpricing theories collectively presume that investment banks discount their estimated value of the going public firm to purposefully provide positive initial returns to the prospective investors. Rock (1986) establishes that discounts are offered on the basis of the necessity to keep uninformed investors in the market and to provide sustainable demand to new issues. Benveniste and Spindt (1989) argue that the discounts are for the mutual benefit of issuers and investors in a mechanism that underwriters interact with institutional investors and forego wealth benefits in exchange for institutions truthfully disclosing the information they have about the firm value. Allen and Faulhaber (1989) maintain that larger discounts and ensuing larger initial returns signal quality of the issue. Shiller (1990) associates discounts with an effort to avoid undersubscription and to impress investors. Theorists tend to agree that underwriter discounts lead to positive aftermarket returns. However, one needs to be informed about the valuation procedure of IPOs to maintain that underwriters purposefully underprice issues by discounting them. Ritter and Welch (2002) note that asymmetric information theories provide insufficient explanation to underpricing and one needs to delve into the valuation procedure. Although unobservable in the US due to disclosure restrictions and the quiet period (Ritter, 2003), regulations enable observation of valuation in the European IPOs. Recent evidence from French IPOs (Roosenboom, 2012) supports that discounts are 
positively related to initial returns. This is consistent with the prominent view that larger discounts could be offered on the basis of publicity and IPO promotion since positive publicity could lead to better investor attention and consequently larger initial returns. ${ }^{1}$ Turkish IPOs are; however, considerably different from French, US and most European IPOs due to the dominance of fixed price offerings and larger retail investor participation. ${ }^{2}$ The informational environment is, consequently, more asymmetric. Chowdhry and Sherman (1996a) argue that in markets with large retail investor allocations, underwriters may relatively overvalue the issue since they lack the incentive required for underpricing to prevent a winner's curse to uninformed investors. This would suggest that underwriter discounts in such markets may not be designed to induce positive initial returns.

Bookbuilding is often central to the underpricing theories, where discretionary allocation power of underwriters and their interaction with institutional investors is incorporated into the offer price. Although popularity of the bookbuilding has increased worldwide (Sherman, 2005; Gajewski \& Gresse, 2006), fixed price offerings are still popular in many emerging markets (Loughran et al., 1994; Hsu et al., 2009; Low \& Yong, 2011). Major differences exist between the two techniques; in particular, underwriters often lack discretionary allocation power and offer price is set prior to soliciting investors' private information in fixed price offerings (Benveniste \& Busaba, 1997). However, their discretionary valuation power remains, which they may use to their advantage in markets with high density of uninformed investors. Existing evidence indicates that retail investors are allocated a higher proportion of overpriced offerings (Aggarwal et al., 2002) and underwriters tend to reallocate overvalued shares to retail investors (Bonaventura et al., 2018). On the other hand, theorists argue that fixed price offerings could be underpriced more to attract retail investor demand in an environment where investors can observe subscription decisions, because the cost of creating demand cascades is higher than extracting investor information (Welch, 1992; Benveniste \& Busaba, 1997). The risk of bad news leakage during the subscription period could lead to even greater underpricing in fixed price offerings (Chowdhry \& Sherman, 1996b). Previous studies do not investigate valuation characteristics of bookbuilding offerings vis-à-vis fixed price issues; however, several papers provide tests of underpricing with mixed results. For example, Derrien and Womack (2003) and Huang et al. (2017) find higher initial returns for book-built offerings, while Chowdhry and Sherman (1996b) and Pandey (2004) find that fixed price offerings produce larger initial returns. Loughran et al. (1994) demonstrate that the initial returns are larger for issuers fixing the offer price earlier. Clarke et al. (2016) show that book-built offerings are underpriced even after discretionary allocation capacity of underwriters is removed. Derrien (2005) provides a sentiment-based explanation to this conundrum, in which underwriter opts for a price between the intrinsic value and the hypothetical

\footnotetext{
${ }^{1}$ Larger media coverage does not always lead to higher initial returns. Chen et al. (2019) find a structural shift in the US market from pre- to post-2000 IPOs associated with enhanced visibility and reduced asymmetric information. While larger media coverage is associated with higher initial returns in the pre-2000 period, it leads to lower initial returns in the post-2000 market.

2 Gajewski and Gresse (2006) review the European IPO markets. Their survey reveals that 71.6\% of French IPOs, 96.9\% of German IPOs, and 99.3\% of Italian IPOs between 1995 and 2004 use bookbuilding as the method of offering. The fraction of fixed price IPOs ranges from $0.7 \%$ in Italian IPOs to $8.8 \%$ in French IPOs, while $83.5 \%$ of Turkish IPOs are offered via a fixed price mechanism in the same period. Deloof et al. (2009) report a $73.5 \%$ bookbuilding ratio for a sample of 49 Belgian offerings.
} 
price optimistic noise trader is willing to pay. The sustained involvement of the uninformed trader in the new issue market ensures that the issue may be overvalued and underpriced at the same time. Derrien (2005) tests this theory in a sample of French modified bookbuilding IPOs, where $10 \%$ of the allocations are reserved for retail investors. Similarly in Turkey, regulations stipulate that $10 \%$ of the allocations are to be reserved for individual investors, regardless of the offer type. The median retail (institutional) investor allocation equals to $67 \%(33 \%)$ in the sample. ${ }^{3}$ Therefore, the implications are expected to be extrapolated to the Turkish IPO market due to the high proportion of retail investors. In the Derrien's (2005) setting, underwriters would pre-emptively overvalue the issuer and determine discounts based on the optimistic bias in their value estimates so that the discount does not fully offset their optimism. This line of reasoning is also consistent with the anchoring theory of Hundtofte and Torstila (2018), who show that under- or over-valuation of IPOs is inversely related to the aftermarket returns, since share price is adjusted as the firm reverts to its intrinsic value. Roosenboom (2012) concludes that underwriters strategically overvalue the issues to advertise larger discounts. This would suggest a strong positive correlation between the valuation error and discounts. If discounts are offered with the purpose of inducing underpricing, at the minimum they must be proportional to the valuation error. A lower discount would overvalue the issue; however, may still lead to positive initial returns if investors are optimistic. Based on this discussion, three testable hypotheses are produced below:

H1: Underwriter discounts are positively associated with the optimistic valuation bias, and negatively associated with underpricing.

$\mathrm{H} 2$ : Bookbuilding offerings are associated with lower valuation bias, higher valuation accuracy, larger discounts and underpricing relative to fixed price offerings.

H3: Overall intensity of demand and retail intensity of demand are positively associated with underpricing.

The valuation literature utilizes three main streams of assessment. The first stream uses academic's value estimation based on peer multiples matched on industry, and other firm characteristics. Kim and Ritter (1999), Purnanandam and Swaminathan (2004), and Colaco et al. (2017) are prominent relevant examples. The second stream relies on financial analysts' forecasts. For example, Chahine (2004) shows that optimistic earnings forecasts of analysts lead to poor post-issue performance in French IPOs. Paleari and Vismara (2007) reach a similar conclusion; they find that financial analysts are overoptimistic about the future sales forecasts of going public firms. This investigation concerns the third stream, which relies on the official IPO prospectuses and valuation reports approved by the relevant regulatory authorities. Disclosure regulations in several European markets allow researchers to directly observe underwriters' valuation procedure. Deloof et al. (2009) and Roosenboom (2012) compare bias and accuracy of different valuation methods in Belgian and French IPOs. Paleari et al. (2014) present evidence that underwriters in French, German and Italian IPOs systematically exclude peers with low multiples to introduce optimistic bias in their value estimates. Vismara et al. (2015) document that peer multiples used by underwriters subsequent

\footnotetext{
${ }^{3}$ Developed markets typically have higher institutional investor allocation. For example, Aggarwal et al. (2002) find $74.26 \%$ median institutional allocation in the US book-built offerings. Jenkinson and Jones (2004) report an $84 \%$ institutional allocation for a sample of 27 European IPOs.
} 
to IPO are lower than those used to value IPO. They interpret this finding as an indicator of upward valuation bias and an attempt to make IPOs appear conservatively priced by selective use of higher peer multiples. Bonaventura and Giudici (2017) compare underwriter cash flow forecasts with realised cash flows following the IPO, concluding that underwriters significantly overestimate future profitability. Lopez and Martin (2019) discuss realized valuation multiples and marketability discount in Spanish acquisitions, recommending standard and fair valuation discounts to improve accuracy of investment decisions. All three streams of the literature appear to agree that underwriters overvalue new issues, with varying degrees of bias and accuracy across different valuation techniques. This study aims to further their findings to the Turkish market and improve the understanding of underpricing.

This study extends and bears relevance to several studies on Turkish IPOs, which investigate the existence and determinants of underpricing (Kiymaz, 2000; Durukan, 2002; Bildik \& Yilmaz, 2008). None of them; however, utilize the valuation reports and underwriter discounts to test the underpricing theories. This is partly because publication of the valuation reports were voluntary prior to the SPK (2013a). For example, Kiymaz (2000) uses size, age and gross proceeds information asymmetry proxies for the winner's curse hypothesis, claiming support for Rock (1986). Similarly, Durukan (2002) finds support for the winner's curse relying on the post-issue intraday returns. This research extends the Turkish literature as well as the general finance literature by providing the direct tests of the relationship between initial returns and underwriter discounts implicit in the pricing theories.

\section{Data and IPO characteristics}

The list of IPOs between April 2010 and September 2018 is obtained from the SPK and supplemented with IPO prospectuses, valuation reports, and various post-issue filings from KAP. The initial list contains 123 IPOs, of which valuation reports are available for 113 firms. While SPK (2013a, 2013b) regulate disclosure of valuation reports prior to going public, previous issuers also often disclose valuation information either in the prospectus or in the supplementary valuation report. Various type of data on the valuation methodology, ownership, fair value, offer price, and underwriter discount are collected from pre-issue filings. Data on allocations, investor demand and oversubscription are collected from post-issue filings. Share price information is provided by Borsa Istanbul (BIST) Data Store. Final sample consists of 113 IPOs for which valuation procedure could be identified. The IPOs before 2010 are excluded for two reasons: First, these years coincide with a worldwide financial crisis and ensuing cold markets, during which few firms choose to go public. Second, the SPK adopted Issue Directive I.40 on April 2010 to maintain consistency with the European regulations, allowing underwriters discretionary allocation power within the specified investor groups.

Table 1 shows the distribution of IPOs and offer characteristics. The number of IPOs are large and in double digits in the first five years, while their number is reduced to single digits after 2014. The relatively large number of offerings between 2010 and 2014 could be explained by market timing of issuers during cold markets as there was only one IPO in 2008 and 2009. This can also be partly attributed to a SPK campaign initiated in 2010 to encourage family-oriented and public-averse Turkish firms to go public. The declining pattern in 
the post-2014 years coincides with a period of political and economic instability in Turkey, from which the markets are yet to fully recover. Fixed price is the dominant type of offering mechanism. $84(74.3 \%)$ of the going public firms are offered via fixed price method and 29 (25.7\%) via bookbuilding method. More than half of the IPOs (57 IPOs; $50.4 \%$ ) issue new shares to increase capital, 15 (13.3\%) of the issuers sell existing shares only, and 41 (36.3\%) of the firms go public to sell both new and existing shares.

Table 1. Sample distribution and offer characteristics

\begin{tabular}{|c|c|c|c|c|c|c|c|c|c|}
\hline \multirow{2}{*}{ Year } & \multicolumn{2}{|c|}{ Number of IPOs } & & \multicolumn{2}{|c|}{ Pricing Method } & & \multicolumn{3}{c|}{ Shares Offered } \\
\cline { 2 - 6 } & Population & Sample & & $\begin{array}{c}\text { Fixed } \\
\text { Price }\end{array}$ & Bookbuilding & & Primary & Existing & Both \\
\hline 2010 & 22 & 16 & & 9 & 7 & & 3 & 3 & 10 \\
\hline 2011 & 27 & 23 & & 12 & 11 & & 12 & 2 & 9 \\
\hline 2012 & 25 & 25 & & 23 & 2 & & 18 & 1 & 6 \\
\hline 2013 & 18 & 18 & & 16 & 2 & & 11 & 1 & 6 \\
\hline 2014 & 13 & 13 & & 10 & 3 & & 6 & 3 & 4 \\
\hline 2015 & 5 & 5 & & 5 & - & & 3 & - & 2 \\
\hline 2016 & 1 & 1 & & 1 & - & & - & - & 1 \\
\hline 2017 & 3 & 3 & & 2 & 1 & & - & 2 & 1 \\
\hline 2018 & 9 & 9 & & 6 & 3 & & 4 & 3 & 2 \\
\hline Total & 123 & 113 & & 84 & 29 & & 57 & 15 & 41 \\
\hline
\end{tabular}

\subsection{Valuation techniques}

Table 2 presents valuation methods and their weights. Since a typical IPO is valued by multiple methods, sum of all methods exceeds the sample size. Valuation techniques are summarized in four main groups: market multiples (MM), discounted cash flow (DCF), net asset value (NAV) and other methods. MM is the most popular technique, underwriters utilize MM in 103 (91.15\% of) cases to reach a value estimate. The term refers to peer multiples and index multiples together. Underwriters often use both of them and estimate the MM value by taking the weighted average of the two. Peer multiples may also vary by issuer, underwriters typically seek domestic peers and resort to foreign peer and takeover multiples if a suitable domestic peer does not exist. Domestic peer multiples are used in 78 firms (69\%), followed by foreign peer (36 firms, 31.8\%) and takeover multiples (4 firms, 3.53\%). Frequent use of foreign peer multiples to value Turkish IPOs is consistent with an emerging market reality that a suitable peer may not always exist when the market is less populated (How et al., 2007; Firth et al., 2008). Index multiples are used in 58 IPOs (51.32\%). The indices could be the corresponding industry index, BIST100, BIST Composite, Developing Enterprises Market (GIP) Index, depending on which index the issuer is going to be a part of. Underwriters use four multiples to obtain value estimates. Enterprise value-to-earnings (EV/E) is the most frequently used with 72 IPOs (63.71\%), followed by market-to-book (M/B) multiple (67 firms, 59.29\%), price-to-earnings (P/E) multiple (61 firms, 53.98\%), and enterprise value-to-sales 
(EV/S) multiple (52 firms, 46\%). DCF technique is used in 94 IPOs, covering $83.18 \%$ of the sample. Net asset value (NAV) method is used to value 17 IPOs (15.04\%). Other methods (e.g. sum of the parts, residual income) are used to value 13 issuers (11.5\%). The percentage weights of each method in the fair value estimate is reported in the last two columns. MM and DCF techniques carry the largest weights and each explain nearly half of the fair value when they are used. Because underwriters frequently combine these methods, it is not surprising to find this result. In $82(72.5 \%)$ of the issuers, the fair value is determined exclusively by MM and DCF methods, in line with the view that inaccuracy of the DCF necessitates supplementary use of MM (Kim \& Ritter, 1999).

Several important points can be inferred from Table 2. MM technique is the most popular and covers nearly $48 \%$ of the fair value estimate. This coverage is comparable to Roosenboom (2012), emphasizing the practical importance of recognizing other techniques in firm valuation. MM and DCF together estimate a combined $87.22 \%$ of the total IPO value. The frequency of the P/E multiple is lower than that of European markets, $\mathrm{P} / \mathrm{E}$ multiple is used in $53.98 \%$ of the issuers compared to the larger $83.77 \%$ utilization in Roosenboom (2012). This finding is important because $\mathrm{P} / \mathrm{E}$ ratio is widely used in the literature by mainstream researchers such as Alford (1992) and Kim and Ritter (1999). The relative low intensity of P/E contrasts with the high intensity of EV/E ratio, which is used in $63.71 \%$ of IPOs, compared to a much lower $24.56 \%$ in Roosenboom (2012) and 49\% in Paleari et al. (2014). Turkish underwriters use a smaller set of four multiples relative to their European counterparts which use at least six multiples to estimate IPO value (Roosenboom, 2012; Paleari et al., 2014). The DDM, for example, is highly popular in French and Belgian IPOs because they tend to disclose their pay-out policy in the prospectus (Deloof et al., 2009; Roosenboom, 2012). Turkish IPOs, on the other hand, rarely make such long-term disclosure.

Table 2. IPO valuation methods

\begin{tabular}{|l|c|c|c|c|}
\hline \multicolumn{1}{|c|}{ Technique } & $\mathrm{N}$ & $\%$ & $\begin{array}{c}\text { Average method } \\
\text { weight as } \\
\text { percentage fair } \\
\text { value }\end{array}$ & $\begin{array}{c}\text { Average method } \\
\text { weight conditional } \\
\text { on using this } \\
\text { method }\end{array}$ \\
\hline Market multiples & 103 & $91.15 \%$ & $47.98 \%$ & $53.66 \%$ \\
\hline Peer multiples & 93 & $82.30 \%$ & - & - \\
\hline - Domestic peer multiples & 78 & $69.02 \%$ & - & - \\
\hline - Foreign peer multiples & 36 & $31.85 \%$ & - & - \\
\hline - M\&A peer multiples & 4 & $3.53 \%$ & - & - \\
\hline Index multiples & 58 & $51.32 \%$ & - & - \\
\hline M/B multiple & 67 & $59.29 \%$ & - & - \\
\hline P/E multiple & 61 & $53.98 \%$ & - & $49.84 \%$ \\
\hline EV/E multiple & 72 & $63.71 \%$ & - & $57.39 \%$ \\
\hline EV/S multiple & 52 & $46.01 \%$ & - & $65.62 \%$ \\
\hline Discounted cash flows & 94 & $83.18 \%$ & $39.26 \%$ & - \\
\hline Net asset value & 17 & $15.04 \%$ & $8.12 \%$ & - \\
\hline Other methods & 13 & $11.50 \%$ & $4.64 \%$ & - \\
\hline
\end{tabular}




\subsection{Descriptive statistics and underpricing}

Table 3 presents relevant descriptive statistics for the IPO process and the preceding valuation. The statistics for full sample, fixed price and bookbuilding IPOs are presented separately to enable comparison. The average issuer is 16.67 years old, and controlled by a single family. On average, $8.29 \%$ of the existing shares sold and capital is increased by $31.61 \%$ in the IPO, while $29.13 \%$ of the firm remains public after the offering. The average investment bank underwrites $13.27 \%$ of the annual IPO value, and the sample includes 22 different lead underwriters. Institutional investors are allocated $39.31 \%$ and retail investors are allocated $60.69 \%$ of the shares on average. ${ }^{4}$ The average IPO is oversubscribed 2.64 times, which is much lower than the extreme oversubscription rates reported for other emerging markets (Chowdhry \& Sherman, 1996b). The average going public firm brings $\$ 48.21$ million in gross proceeds, it is valued at $\$ 261.18$ million before discounting, and at $\$ 191.95$ million at the final offer price.

The average (median) price discount announced by underwriters is $23.2 \%(21 \%)$, with a minimum of $0 \%$ and a maximum of $46 \%$. This statistic is larger than the $18.21 \%$ average discount reported by Roosenboom (2012). The average underwriter uses two different techniques to estimate fair value. Note that MM method is counted only once since various multiples used by underwriters are ultimately incorporated into a single MM value. The raw average (median) underpricing is $5.18 \%(0.8 \%)$, while average (median) market-adjusted underpricing is a close $5.15 \%(1.45 \%)$. The raw and market-adjusted monthly average daily returns are also calculated, which are slightly larger than initial returns. Overall, IPOs provide considerably lower initial and monthly average returns than discounts advertised in the valuation reports. This finding is important because an official price discount carries an implicit promise that the share will exhibit a proportional increase in value after going public. This promise does not materialise in the sample, implying that underwriters overvalue the firms before discounting the price.

Table 3. Descriptive statistics and underpricing

\begin{tabular}{|l|c|c|c|c|c|c|c|c|c|}
\hline \multirow{2}{*}{ Variable } & \multicolumn{2}{|c|}{ Full Sample } & \multicolumn{2}{c|}{$\begin{array}{c}\text { Bookbuilding } \\
\text { (BB) }\end{array}$} & \multicolumn{2}{c|}{$\begin{array}{c}\text { Fixed Price } \\
(\mathrm{FP})\end{array}$} & \multicolumn{2}{c|}{$\begin{array}{c}\text { Differences } \\
\text { (BB vs. FP) }\end{array}$} & \multirow{2}{*}{$\mathrm{N}$} \\
\cline { 2 - 10 } & Mean & Median & Mean & Median & Mean & Median & Mean & Median & \\
\hline 1 & 2 & 3 & 4 & 5 & 6 & 7 & 8 & 9 & 10 \\
\hline Age & 16.67 & 15 & 18.1 & 14 & 16.18 & 15 & 1.92 & -1 & 113 \\
\hline Family & 0.65 & 1 & 0.58 & 1 & 0.68 & 1 & -0.1 & 0 & 113 \\
\hline $\begin{array}{l}\text { Participation } \\
\text { ratio (\%) }\end{array}$ & 8.29 & 0 & 12.15 & 8 & 6.95 & 0 & $5.2^{* *}$ & $8^{* *}$ & 113 \\
\hline $\begin{array}{l}\text { Dilution } \\
\text { ratio (\%) }\end{array}$ & 31.61 & 32 & 25.94 & 27.2 & 33.57 & 33.42 & -7.63 & $-6.22^{*}$ & 113 \\
\hline $\begin{array}{l}\text { Public ratio } \\
\text { (\%) }\end{array}$ & 29.13 & 29.51 & 28.15 & 29.51 & 29.47 & 29.7 & -1.32 & -0.19 & 113 \\
\hline
\end{tabular}

\footnotetext{
${ }^{4}$ Employees of the issuing firms are considered as retail investors since they are subject to the individual investor allocation principles in accordance with the SPK regulations.
} 
Continued Table 3

\begin{tabular}{|c|c|c|c|c|c|c|c|c|c|}
\hline 1 & 2 & 3 & 4 & 5 & 6 & 7 & 8 & 9 & 10 \\
\hline $\begin{array}{l}\text { Underwriter } \\
\text { reputation } \\
(\%)\end{array}$ & 13.27 & 7.06 & 23.78 & 10.47 & 9.64 & 6.71 & $14.14^{\star * *}$ & $3.76^{\star * *}$ & 113 \\
\hline $\begin{array}{l}\text { Institutional } \\
\text { allocation } \\
\text { (\%) }\end{array}$ & 39.31 & 33 & 55.95 & 46 & 25.64 & 13.25 & $30.31^{* * *}$ & $32.75^{\star * *}$ & 51 \\
\hline $\begin{array}{l}\text { Retail } \\
\text { allocation } \\
(\%)\end{array}$ & 60.69 & 67 & 44.05 & 54 & 74.36 & 86.75 & $-30.31^{\star * *}$ & $-32.75^{\star * *}$ & 51 \\
\hline $\begin{array}{l}\text { Oversubs- } \\
\text { cription }\end{array}$ & 2.64 & 1.54 & 2.52 & 1.7 & 2.73 & 1.5 & -0.21 & 0.2 & 57 \\
\hline $\begin{array}{l}\text { Institutional } \\
\text { oversubs- } \\
\text { cription }\end{array}$ & 2.38 & 1.49 & 2.04 & 1.38 & 2.73 & 1.49 & -0.69 & -0.11 & 43 \\
\hline $\begin{array}{l}\text { Retail over- } \\
\text { subscription }\end{array}$ & 3.74 & 1.75 & 4.81 & 2.04 & 2.62 & 1.37 & 2.19 & 0.67 & 43 \\
\hline Profitability & 9.66 & 7.85 & 11.01 & 8.48 & 9.2 & 7.52 & 1.81 & 0.96 & 113 \\
\hline $\begin{array}{l}\text { Gross } \\
\text { proceeds } \\
(\text { mil \$) }\end{array}$ & 48.21 & 10.76 & 145.4 & 62.11 & 14.65 & 7.54 & $130.75^{\star * *}$ & $54.57^{\star * \star}$ & 113 \\
\hline $\begin{array}{l}\text { Fair value } \\
\text { estimate } \\
(\mathrm{mil} \$)\end{array}$ & 261.18 & 49.66 & 793.02 & 372.19 & 77.58 & 34.11 & 715.44 & 338.08 & 113 \\
\hline $\begin{array}{l}\text { MM } \\
\text { estimate } \\
(\text { mil \$) }\end{array}$ & 203.75 & 35.11 & 699.75 & 237.52 & 63.85 & 25.96 & 635.9 & 211.56 & 100 \\
\hline $\begin{array}{l}\text { DCF } \\
\text { estimate } \\
\text { (mil \$) }\end{array}$ & 132.86 & 42.52 & 402.58 & 218.81 & 67.36 & 33.88 & 335.22 & 184.93 & 87 \\
\hline $\begin{array}{l}\text { NAV } \\
\text { estimate } \\
(\mathrm{mil} \mathrm{\$ )}\end{array}$ & 461 & 129.87 & 1179.74 & 428.54 & 161.52 & 76.73 & 1018.22 & 351.81 & 17 \\
\hline $\begin{array}{l}\text { Other } \\
\text { methods } \\
\text { estimate } \\
(\text { mil \$) }\end{array}$ & 670.51 & 539.13 & 995.83 & 1036.7 & 345.18 & 265.12 & 650.65 & 771.58 & 8 \\
\hline $\begin{array}{l}\text { Final offer } \\
\text { value (mil \$) }\end{array}$ & 191.95 & 36.7 & 580 & 270.66 & 57.97 & 26.15 & 522.03 & 244.51 & 113 \\
\hline $\begin{array}{l}\text { First day } \\
\text { market value } \\
(\text { mil \$) }\end{array}$ & 197.28 & 42.19 & 593.08 & 262.35 & 60.64 & 28.41 & 532.44 & 233.94 & 113 \\
\hline $\begin{array}{l}\text { Monthly } \\
\text { average m. } \\
\text { value (mil \$) }\end{array}$ & 198.88 & 39.32 & 594.62 & 239.84 & 62.25 & 28.32 & 532.37 & 211.52 & 113 \\
\hline $\begin{array}{l}\text { Deliberate } \\
\text { discount (\%) }\end{array}$ & 23.2 & 21 & 27.36 & 27.35 & 21.8 & 20.1 & $5.56^{* * *}$ & $7.25^{\star *}$ & 113 \\
\hline
\end{tabular}


End of Table 3

\begin{tabular}{|c|c|c|c|c|c|c|c|c|c|}
\hline 1 & 2 & 3 & 4 & 5 & 6 & 7 & 8 & 9 & 10 \\
\hline $\begin{array}{l}\text { First day } \\
\text { return }(\%)\end{array}$ & $5.18^{\star \star \star}$ & $0.8^{* * *}$ & $2.72^{\star *}$ & 0.32 & $6.02^{* * *}$ & $1.37^{\star * *}$ & $-3.3^{*}$ & 1.05 & 113 \\
\hline $\begin{array}{l}\text { Market adj. } \\
\text { first day } \\
\text { return (\%) }\end{array}$ & $5.15^{\star \star \star}$ & $1.45^{* * *}$ & $2.82^{\star *}$ & -0.00 & $5.96^{* * *}$ & $1.71^{\star * \star}$ & -3.14 & -1.71 & 113 \\
\hline $\begin{array}{l}\text { Monthly } \\
\text { average daily } \\
\text { return (\%) }\end{array}$ & $7.98^{\star \star \star}$ & $3.16^{* * *}$ & 3.34 & -0.15 & $9.59^{* * *}$ & $4.7^{\star \star *}$ & $-6.25^{\star}$ & $-4.85^{\star *}$ & 113 \\
\hline $\begin{array}{l}\text { Market adj. } \\
\text { monthly av. } \\
\text { return (\%) }\end{array}$ & $8.02^{\star \star \star}$ & $2.82^{* * *}$ & 3.37 & -1.37 & $9.62^{* * *}$ & $4.8^{\star * *}$ & -6.25 & $-6.17^{\star *}$ & 113 \\
\hline
\end{tabular}

Table displays summary statistics. Age is calculated as going public year less founding year. Family is a dummy variable, equal to 1 if issuer is family owned, 0 otherwise. The combined ownership of at least two members of family must be more than $50 \%$ of equity and 1 family member must be on board to qualify. Participation ratio is percent of existing shares sold relative to pre-issue equity. Dilution ratio is new shares issued divided by pre-issue equity. Public ratio is number of publicly traded shares divided by post-issue equity. Underwriter reputation is calculated as sum of gross proceeds from IPOs lead-managed by investment bank j, divided by gross proceeds from all IPOs in that particular year. Institutional allocation is the percentage shares distributed to institutional investors, as reported in the post-issue filings. Retail allocation is the percentage shares distributed to individual investors, as reported in the post-issue filings. Oversubscription ratios are calculated from post-issue reports as preliminary investor demand divided by shares allocated to the particular investor type. Profitability is computed as earnings before interest and taxes divided by total assets in the preceding year. Gross proceeds is computed as number of shares sold multiplied by offer price, including overallotment options. Deliberate discount is the percentage discount over the fair value estimate taken from valuation reports for fixed price offerings and midpoint of the discount range for bookbuilding offerings. Initial returns are computed as first trading day closing price minus offer price, divided by offer price. Market-adjusted returns are computed as initial return minus corresponding daily return on the BIST Composite Index. Values are converted to US Dollars using Central Bank bid exchange rate on the first day of trading. Significance of means and medians are tested by a t-test and sign rank test. ${ }^{* *},{ }^{* *}$, and * show statistical significance at $1 \%, 5 \%$, and $10 \%$ level.

Several important differences are observed between the subsamples of fixed price and bookbuilding offerings. Existing shareholders sell more of their holdings, IPOs are underwritten by more reputable investment banks, institutional investors are allocated considerably more shares, and on average, IPOs are discounted 5.56\% more in book-built offerings relative to the fixed price offerings. As expected, book-built IPOs are considerably larger than fixed price IPOs and they yield more gross proceeds. There are no significant differences in age, oversubscription and profitability. Most importantly; however, most book-built IPOs do not provide positive initial returns and they are not more underpriced than fixed price IPOs. On the contrary, book-built offerings appear to be more overpriced as they provide lower initial and monthly average daily returns, although differences are only significant in the latter. This finding contrasts Benveniste and Spindt (1989) information extraction explanation to underpricing. The fact that book-built offerings are not underpriced even though they are offered with larger price discounts indicates that they have larger inherent valuation bias. The bias and accuracy of the methods are investigated in the next subsection. 
Table 4. Bias and accuracy of valuation methods

\begin{tabular}{|c|c|c|c|c|c|c|c|c|c|}
\hline \multirow{2}{*}{ Variable } & \multicolumn{2}{|c|}{ Full Sample } & \multicolumn{2}{|c|}{$\begin{array}{l}\text { Bookbuilding } \\
\text { (BB) }\end{array}$} & \multicolumn{2}{|c|}{$\begin{array}{l}\text { Fixed Price } \\
\text { (FP) }\end{array}$} & \multicolumn{2}{|c|}{ Differences } & \multirow{2}{*}{$\mathrm{N}$} \\
\hline & Mean & $\begin{array}{l}\text { Me- } \\
\text { dian }\end{array}$ & Mean & $\begin{array}{l}\text { Me- } \\
\text { dian }\end{array}$ & Mean & $\begin{array}{l}\text { Me- } \\
\text { dian }\end{array}$ & Mean & Median & \\
\hline \multicolumn{7}{|c|}{ Panel A: Valuation bias } & \multicolumn{3}{|c|}{ BB vs. FP } \\
\hline $\begin{array}{l}\text { Fair value estimate } \\
(\%)\end{array}$ & 27.42 & 24.75 & 36.88 & 31.34 & 24.16 & 23.7 & $12.72^{* * *}$ & $7.64^{\star *}$ & 113 \\
\hline MM estimate (\%) & 11.53 & 11.54 & 29.48 & 31.62 & 6.47 & 10.09 & $23.01^{* * *}$ & $21.53^{* * *}$ & 100 \\
\hline DCF estimate (\%) & 44.96 & 41.02 & 56.44 & 51.98 & 42.17 & 37.65 & $14.27^{\star}$ & $14.33^{\star}$ & 87 \\
\hline NAV estimate (\%) & 41.43 & 42.94 & 58.1 & 63.35 & 34.48 & 39.56 & 23.62 & 23.79 & 17 \\
\hline Other methods (\%) & 26.42 & 19.25 & 44.8 & 38.02 & 8.05 & -6.03 & 36.75 & 44.05 & 8 \\
\hline \multicolumn{7}{|c|}{ Panel B: Valuation accuracy } & \multicolumn{3}{|c|}{ BB vs. FP } \\
\hline $\begin{array}{l}\text { Fair value estimate } \\
(\%)\end{array}$ & 28.99 & 24.75 & 37.91 & 31.34 & 25.91 & 23.7 & $12^{* *}$ & $7.64^{*}$ & 113 \\
\hline MM estimate (\%) & 26.84 & 21.15 & 37.63 & 33.89 & 23.79 & 19.41 & $13.84^{* * *}$ & $14.48^{\star \star}$ & 100 \\
\hline DCF estimate (\%) & 47.63 & 41.52 & 57.64 & 51.98 & 45.17 & 38.61 & 12.47 & 13.37 & 87 \\
\hline NAV estimate (\%) & 48.9 & 42.94 & 58.1 & 63.35 & 45.06 & 41.57 & 13.04 & 21.78 & 17 \\
\hline Other methods (\%) & 37.4 & 30.05 & 44.8 & 38.02 & 30.03 & 19.74 & 14.77 & 18.28 & 8 \\
\hline \multicolumn{7}{|c|}{ Panel C: Pairwise comparison: MM vs. DCF } & \multicolumn{3}{|c|}{ MM vs. DCF } \\
\hline MM (\%) - Bias & 7.81 & 8.86 & 23.28 & 31.62 & 4.62 & 8.48 & $-36.11^{* * *}$ & $-31.84^{* * *}$ & 82 \\
\hline DCF $(\%)-$ Bias & 43.92 & 40.7 & 47.84 & 48.41 & 43.12 & 38.19 & $(-7.27)$ & {$[-6.56]$} & 82 \\
\hline MM (\%) - Accuracy & 25.32 & 19.59 & 34.7 & 33.9 & 23.38 & 18.38 & $-20.76^{* * *}$ & $-21.53^{* * *}$ & 82 \\
\hline DCF (\%) - Accuracy & 46.08 & 41.12 & 49.29 & 48.41 & 45.42 & 39.82 & $(-5.34)$ & {$[-4.96]$} & 82 \\
\hline
\end{tabular}

Table shows valuation accuracy and bias. Significance of means and medians is tested by a t-test and sign rank test. t-values are in parentheses, $\mathrm{z}$-values are in brackets. ${ }^{* * *},{ }^{* *}$, and ${ }^{*}$ show significance at $1 \%, 5 \%$, and $10 \%$ level.

\subsection{Valuation accuracy and bias}

This section examines accuracy and bias of the value estimates. Bias and accuracy are defined as signed and absolute prediction errors respectively, where signed errors are calculated as fair value estimate minus first day price, divided by first day price as in Alford (1992), Francis et al. (2000), and Deloof et al. (2009). This estimation assumes that prices on the first day of trading are efficient. This; however, may not be true. Therefore, all calculations are re-estimated using monthly average value and value at the end of price support period. The results of the latter two are consistent with the calculations based on the first day value, and not reported here. Panel A of the Table 4 shows that the average (median) fair value estimate is $27.42 \%(24.75 \%)$ larger than first trading day price. The largest bias is documented in DCF estimates with $44.96 \%$ (41.02\%) average (median) bias, while MM estimates exhibit the lowest bias (11.53\% average, $11.54 \%$ median bias). Panel B reports accuracy of the value estimates. Fair value estimate has an average (median) accuracy of $28.99 \%(24.75 \%)$. MM provides the most accurate, and NAV yields the least accurate estimates. In Panel C, 
a pairwise comparison of the bias and accuracy of MM and DCF methods is conducted. The comparison finds that DCF provides significantly more biased and less accurate value estimates. The average (median) bias of MM estimates is a small 7.81\% (8.86\%), in contrast to the larger $43.92 \%$ (40.07\%) in the DCF model, while the average (median) accuracy is $25.32 \%$ (19.59\%) for MM and 46.08\% (41.12\%) for DCF estimates. Significant differences exist between bookbuilding and fixed price offerings in the bias and accuracy of fair value estimates as well as MM estimates. DCF method is only weakly biased in bookbuilding offerings against fixed price offerings, while NAV and other methods are not more biased nor less accurate. Given that MM accounts for nearly $48 \%$ of the fair value in the sample, fair value estimates in book-built offerings reflect its importance, as they are significantly more biased and less accurate than fixed price offerings due to strong bias in MM book-built IPOs. The descriptive statistics so far suggest that book-built IPOs exhibit larger discounts and valuation bias; however, not larger initial returns relative to the fixed price IPOs.

\subsection{Underwriter discounts and initial returns}

H1 previously argued that deliberate discounts would be positively associated with the valuation bias and negatively associated with initial returns. Below tests of bias and returns in the subsamples of IPOs stratified by median deliberate discount (DD) are presented. IPOs with larger DD would exhibit higher bias and lower returns if the hypothesis is supported. The subsamples include close number of IPOs; with 54 firms in the low DD and 56 firms in the high DD quantile. Panel A of the Table 5 shows that initial and monthly average returns in the lower DD quantile exhibit significant positive returns, while returns in the high DD quantile are small and not significant at the conventional level and the differences are significant. IPOs in the both quantiles exhibit significant valuation bias; however, firms in the low DD quantile are less biased. The results contrast the conventional wisdom that underwriter discounts are offered to induce underpricing. On the contrary, discounts are more likely to be offered on the basis of IPO promotion (Roosenboom, 2012), and related to the biased valuations.

In Panel B, the sample is stratified by market-adjusted initial returns to investigate the relation between allocations and investor demand. This section covers 51 IPOs that disclosed details of the allocation, and 43 IPOs that disclosed investor demand information. H3 predicts that initial returns would be positively associated with the overall and retail demand intensity. The hypothesis implies that IPOs with negative initial returns (overpriced) would have lower, and IPOs with positive initial returns (underpriced) would have higher investor demand, represented by oversubscription rates. Consistent with this prediction, oversubscription rates in underpriced IPOs are significantly larger. Institutional demand, in addition to the retail demand appears to play a positive role in the underpricing. In contrast to Aggarwal et al. (2002); however, retail investors are not allocated more of the overpriced offerings, the differences in allocations are only weakly significant. This indicates that winner's curse does not exist, or alleviated as in Chowdhry and Sherman's (1996a) framework. The results are robust to using market-adjusted monthly average returns. Overall, the findings are consistent with the optimistic retail investor sentiment (Derrien, 2005) and anchoring (Hundtofte \& Torstila, 2018) explanations to underpricing. 
Table 5. Underwriter discounts, underpricing and investor demand

\begin{tabular}{|c|c|c|c|c|c|c|}
\hline & \multicolumn{2}{|c|}{$\mathrm{DD}<\operatorname{Median}(\mathrm{N}=54)$} & \multicolumn{2}{|c|}{$\mathrm{DD}>\operatorname{Median}(\mathrm{N}=56)$} & \multicolumn{2}{|c|}{ Differences } \\
\hline Panel A & Mean & Median & Mean & Median & Mean & Median \\
\hline \multirow{2}{*}{ Initial return (\%) } & $7.39^{* * *}$ & $5.66^{* * *}$ & $2.87^{\star}$ & 0 & $4.52^{\star * \star}$ & $5.66^{\star * \star}$ \\
\hline & $(5.57)$ & [4.51] & $(2.31)$ & [0.89] & $(2.65)$ & [3.29] \\
\hline \multirow{2}{*}{$\begin{array}{l}\text { Monthly average } \\
\text { return (\%) }\end{array}$} & $14.82^{* * *}$ & $8.02^{\star * *}$ & 1.59 & -0.84 & $13.23^{* * *}$ & $8.86^{* * *}$ \\
\hline & $(4.08)$ & {$[4.07]$} & $(0.87)$ & {$[-0.04]$} & $(3.29)$ & {$[3.45]$} \\
\hline \multirow{2}{*}{$\begin{array}{l}\text { Initial valuation bias } \\
(\%)\end{array}$} & $11.92^{* * *}$ & $12.65^{* * *}$ & $42.44^{* * *}$ & $38.78^{\star * *}$ & $-30.52^{\star * *}$ & $-26.13^{\star * *}$ \\
\hline & $(5.93)$ & [4.71] & $(13.86)$ & {$[6.50]$} & $(-8.27)$ & {$[-7.07]$} \\
\hline \multirow{2}{*}{$\begin{array}{l}\text { Monthly average } \\
\text { valuation bias (\%) }\end{array}$} & $8.48^{\star * \star}$ & $9.16^{* * *}$ & $45.51^{\star * *}$ & $41.32^{* * *}$ & $-37.03^{* * *}$ & $-32.16^{* * *}$ \\
\hline & $(2.83)$ & [2.88] & $(12.76)$ & [6.46] & $(-7.92)$ & {$[-6.75]$} \\
\hline Panel B & \multicolumn{2}{|c|}{$\begin{array}{c}\text { Overpriced; IR }<0 \\
(\mathrm{~N}=30)\end{array}$} & \multicolumn{2}{|c|}{$\begin{array}{l}\text { Underpriced; IR }>0 \\
\quad(\mathrm{~N}=21)\end{array}$} & & \\
\hline $\begin{array}{l}\text { Institutional } \\
\text { allocation (\%) }\end{array}$ & 33.35 & 28.2 & 50.2 & 57.1 & $(-1.89)^{\star}$ & {$[-1.65]^{*}$} \\
\hline Oversubscription & 1.84 & 1.38 & 3.53 & 2.49 & $(-2.86)^{* * *}$ & {$[-2.41]^{\star *}$} \\
\hline $\begin{array}{l}\text { Institutional } \\
\text { oversubscription }\end{array}$ & 1.59 & 1.09 & 3.71 & 2.43 & $(-3.11)^{\star * *}$ & {$[-2.94]^{* * *}$} \\
\hline $\begin{array}{l}\text { Retail } \\
\text { oversubscription }\end{array}$ & 2.33 & 1.32 & 6.12 & 3.52 & $(-2.85)^{\star \star \star \star}$ & {$[-2.61]^{\star * \star}$} \\
\hline
\end{tabular}

Table reports underpricing and valuation bias stratified by median deliberate discount (DD) in Panel A and investor demand stratified by initial returns (IR) in Panel B. Returns are market-adjusted initial and monthly average returns. Median DD is $21 \%$. Significance is tested by a t-test for means and sign rank test for medians. $t$-values are in parentheses, $z$-values are in brackets. ${ }^{* *},{ }^{* *}$, and ${ }^{\star}$ show significance at $1 \%, 5 \%$ and $10 \%$.

\section{Valuation and underpricing regressions}

In this section, the three previously developed hypotheses are tested by means of crosssectional regressions. Tests start with determinants of the valuation bias and accuracy, and continue with deliberate discounts and underpricing models. Various firm, offer and market characteristics used in the prior literature are considered to show that: bookbuilding method is associated with larger bias and lower accuracy, optimistic valuation bias and bookbuilding are significant determinants of deliberate discounts, and discounts are associated with lower initial returns. $\mathrm{H} 1$ predicts $\mathrm{DD}$ to be positively related to the optimistic valuation bias and negatively related to underpricing. In accordance with the bookbuilding theories, $\mathrm{H} 2$ posits that bookbuilding method would be related to lower bias, better accuracy, larger discounts and higher underpricing. $\mathrm{H} 3$ proposes a positive relationship between initial returns and overall oversubscription as well as retail oversubscription rates. Three main constructs are used to model these predictions. The first two constructs relate to the pre-issue valuation period, and the third construct concerns post-issue initial returns. The bias and accuracy model may be written down in Eq. (1) as follows: 


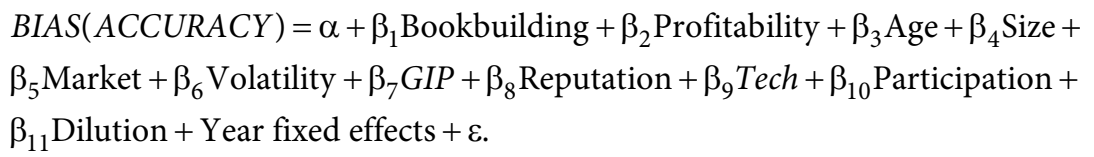

Bookbuilding is a dummy variable that equals 1 if the issuer uses bookbuilding method, 0 otherwise. Size is natural logarithm of the total assets in the year preceding IPO. Market refers to the 90-day BIST Composite Index buy-and-hold return prior to publication of the prospectus or valuation report, whichever is earlier. Volatility is standard deviation of market returns. GIP variable controls for the firms listed on the Developing Enterprises Market. These issuers do not meet the listing criteria on the Main Market. A Tech dummy is also included for issuers who went on to become a member of the technology index, because they tend to be more difficult to value. Other variables are defined in Table 3. Year fixed effects are also included since substantial differences in the number of IPOs are observed across years. The second construct introduces deliberate discounts (DD) and Optimism to the model, where Optimism is a dummy variable equal to 1 if the IPO is overvalued at the fair price estimate, 0 otherwise. The discount model may be written in Eq. (2) as below:

$$
\begin{aligned}
& D D=\alpha+\beta_{1} \text { Optimism }+\beta_{2} \text { Bookbuilding }+\beta_{3} \text { Profitability }+\beta_{4} \text { Age }+ \\
& \beta_{5} \text { Size }+\beta_{6} \text { Market }+\beta_{7} \text { Volatility }+\beta_{8} G I P+\beta_{9} \text { Reputation }+\beta_{10} \text { Tech }+ \\
& \beta_{11} \text { Participation }+\beta_{12} \text { Dilution }+ \text { Year fixed effects }+\varepsilon .
\end{aligned}
$$

In the third construct, underpricing is modelled as a function of $\mathrm{DD}$, bookbuilding, profitability, age, size and market returns. The underpricing model is defined in Eq. (3) below:

$$
\begin{aligned}
& \text { UNDERPRICING }=\alpha+\beta_{1} D D+\beta_{2} \text { Bookbuilding }+\beta_{3} \text { Profitability }+\beta_{4} \text { Age }+ \\
& \beta_{5} \text { Size }+\beta_{6} \text { Market }+\left(\beta_{7} \text { Oversubscription }\right)+\text { Year fixed effects }+\varepsilon .
\end{aligned}
$$

In the model, dependent variable is marked-adjusted initial returns, and Market variable represents BIST Composite Index buy-and-hold returns between publication of the prospectus and first trading day (the period usually ranges from two to three weeks). The last three regressions include Oversubscription, which represents overall demand in the second, retail demand in the third and institutional demand in the fourth underpricing regression. Fixed effects are excluded in the oversubscription regressions to allow enough degrees of freedom. The parameters of the models are estimated via OLS with robust errors. In addition, two median quantile regressions are estimated to examine information in the discounting and underpricing quantiles. The results are presented in Table 6.

The explained variation in regressions ranges from $12.48 \%$ to $52.12 \%$. The first two columns report bias and accuracy regressions, where bookbuilding is the main variable of interest. Offer method, age, size, and pre-issue profitability of the firm are found to be significant determinants of the valuation bias. Bookbuilding method is associated with larger bias and lower accuracy; note that a positive relation with the accuracy variable implies lower accuracy in this construction. One standard deviation increase in bookbuilding is associated with a $24.7 \%$ increase in bias and a $25.6 \%$ reduction in accuracy. Firm age is a well-known proxy for information asymmetries, and it is negatively related to the bias and accuracy. It is also found that larger and more profitable firms are associated with over- and less accurate 


\begin{tabular}{|c|c|c|c|c|c|c|c|c|c|c|c|c|c|c|c|c|c|c|c|c|c|c|}
\hline 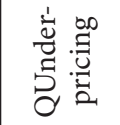 & & & 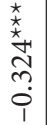 & 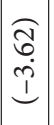 & $\mid \begin{array}{l}0 \\
0 \\
0 \\
0\end{array}$ & 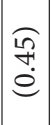 & $\vec{z}$ & $\underset{\mathscr{F}}{\stackrel{\Im}{e}}$ & $\begin{array}{l}\infty \\
0 \\
0 \\
0\end{array}$ & $\begin{array}{l}\hat{乏} \\
\stackrel{\hat{e}}{e}\end{array}$ & 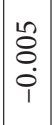 & $\begin{array}{l}\widehat{\tilde{\sigma}} \\
\stackrel{i}{\imath} \\
.\end{array}$ & 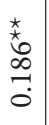 & 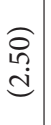 & & & & & & & & \\
\hline 岂: & & & 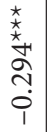 & 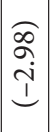 & $\begin{array}{c}m \\
0 \\
0\end{array}$ & $\begin{array}{c}\hat{a} \\
\dot{e}\end{array}$ & $\begin{array}{l}\tilde{\sigma} \\
0 \\
0 \\
1\end{array}$ & ઊ̊ & ○े & ฮ̊ & $\begin{array}{l}+ \\
8 \\
0 \\
1 \\
1\end{array}$ & $\begin{array}{l}\overparen{\Xi} \\
\stackrel{I}{I} \\
\end{array}$ & 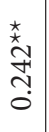 & 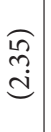 & & & & & & & & \\
\hline 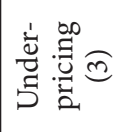 & & & 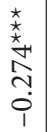 & 尽 & $\mid \begin{array}{l}0 \\
0 \\
0 \\
1 \\
1\end{array}$ & 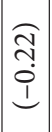 & $\begin{array}{l}\bar{\sigma} \\
0 \\
0 \\
1\end{array}$ & ઼ָ & $\begin{array}{l}8 \\
0 \\
0\end{array}$ & $\begin{array}{l}\overparen{\tilde{g}} \\
\stackrel{+}{0}\end{array}$ & $\mid \begin{array}{l}0 \\
8 \\
0 \\
0 \\
1\end{array}$ & $\begin{array}{l}\overparen{\approx} \\
\stackrel{\imath}{I} \\
\end{array}$ & 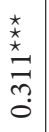 & $\begin{array}{l}\overparen{\Xi} \\
\dot{c} \\
\text { d }\end{array}$ & & & & & & & & \\
\hline 岂 & & & 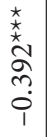 & $\mid \begin{array}{l}\widehat{\varrho} \\
\dot{p} \\
\stackrel{1}{1}\end{array}$ & $\begin{array}{c}0 \\
0 \\
0 \\
i\end{array}$ & $\begin{array}{l}\widehat{\Omega} \\
\hat{\sigma} \\
\underline{1}\end{array}$ & $\begin{array}{l}\infty \\
\tilde{n} \\
0 \\
\dot{1} \\
1\end{array}$ & $\begin{array}{c}\widehat{n} \\
1 \\
0 \\
1 \\
1\end{array}$ & \&্ & $\begin{array}{l}0 \\
0 \\
\dot{0}\end{array}$ & 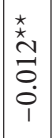 & $\begin{array}{l}\overparen{\vec{n}} \\
i \\
\stackrel{I}{L}\end{array}$ & 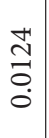 & 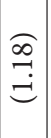 & & & & & & & & \\
\hline 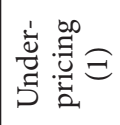 & & & $\begin{array}{l}\stackrel{x}{*} \\
\tilde{N} \\
\tilde{n} \\
0 \\
1\end{array}$ & 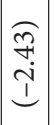 & $\mid \begin{array}{l}2 \\
\tilde{D} \\
0 \\
i \\
1\end{array}$ & $\begin{array}{l}\widehat{\sigma} \\
\hat{\sigma} \\
\underline{1}\end{array}$ & $\begin{array}{l}0 \\
\text { J్ } \\
0 \\
\dot{0}\end{array}$ & 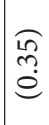 & \&̊ & 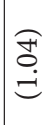 & 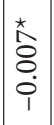 & $\begin{array}{l}\overparen{\Xi} \\
\stackrel{+}{\perp}\end{array}$ & $\begin{array}{l}\text { fि } \\
\text { Oे }\end{array}$ & 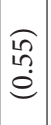 & & & & & & & & \\
\hline 官兽 & 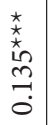 & 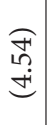 & & & $\mid \begin{array}{c}\infty \\
\tilde{O} \\
0 \\
0\end{array}$ & $\stackrel{\overparen{\Xi}}{\rightleftarrows}$ & $\begin{array}{l}0 \\
0 \\
0 \\
0\end{array}$ & $\begin{array}{l}\text { त् } \\
\infty \\
\stackrel{e}{e}\end{array}$ & $\begin{array}{l}\vec{z} \\
\overrightarrow{0} \\
\dot{i}\end{array}$ & 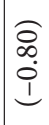 & $\begin{array}{l}\overrightarrow{8} \\
\dot{0} \\
\dot{1}\end{array}$ & 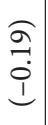 & 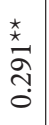 & İ & $\begin{array}{c}\vec{\infty} \\
\underset{n}{m}\end{array}$ & $\begin{array}{l}\mathfrak{d} \\
\stackrel{0}{0}\end{array}$ & $\begin{array}{c}m \\
\hat{\sigma} \\
0\end{array}$ & $\begin{array}{c}\widehat{\vec{f}} \\
\stackrel{e}{e}\end{array}$ & $\begin{array}{l}\mathcal{T} \\
0 \\
0 \\
1\end{array}$ & 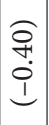 & $\begin{array}{l}\vec{b} \\
0 \\
0 \\
1\end{array}$ & ્ָ \\
\hline
\end{tabular}

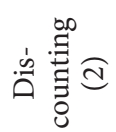

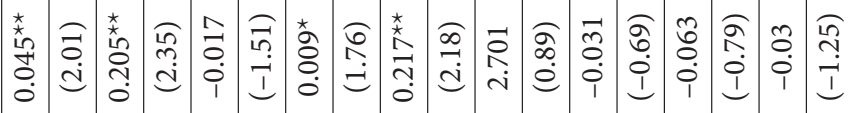

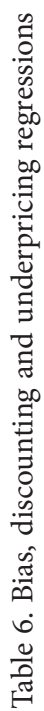

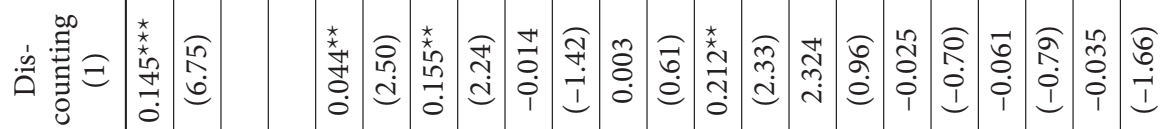

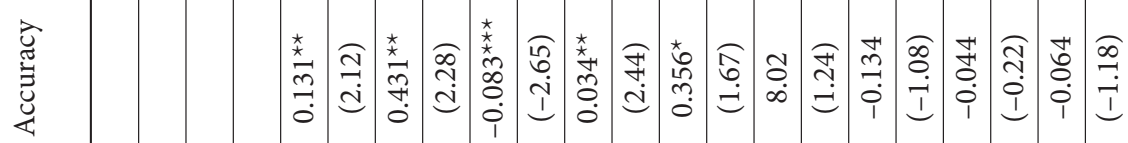

$\stackrel{\mathscr{7}}{\cdots}$

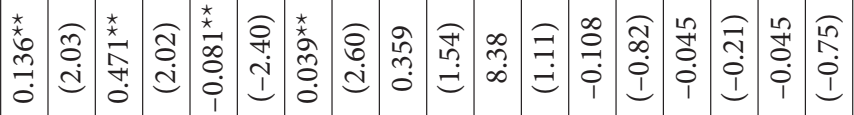

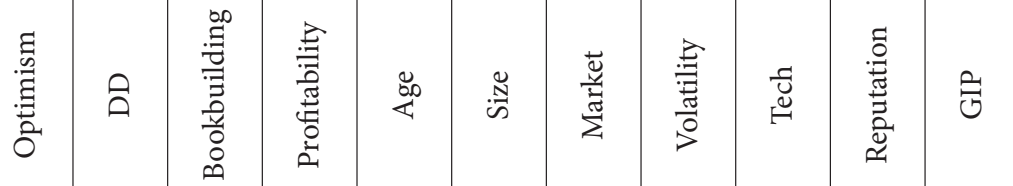


6
0
0
0
0
0
0
ป
1

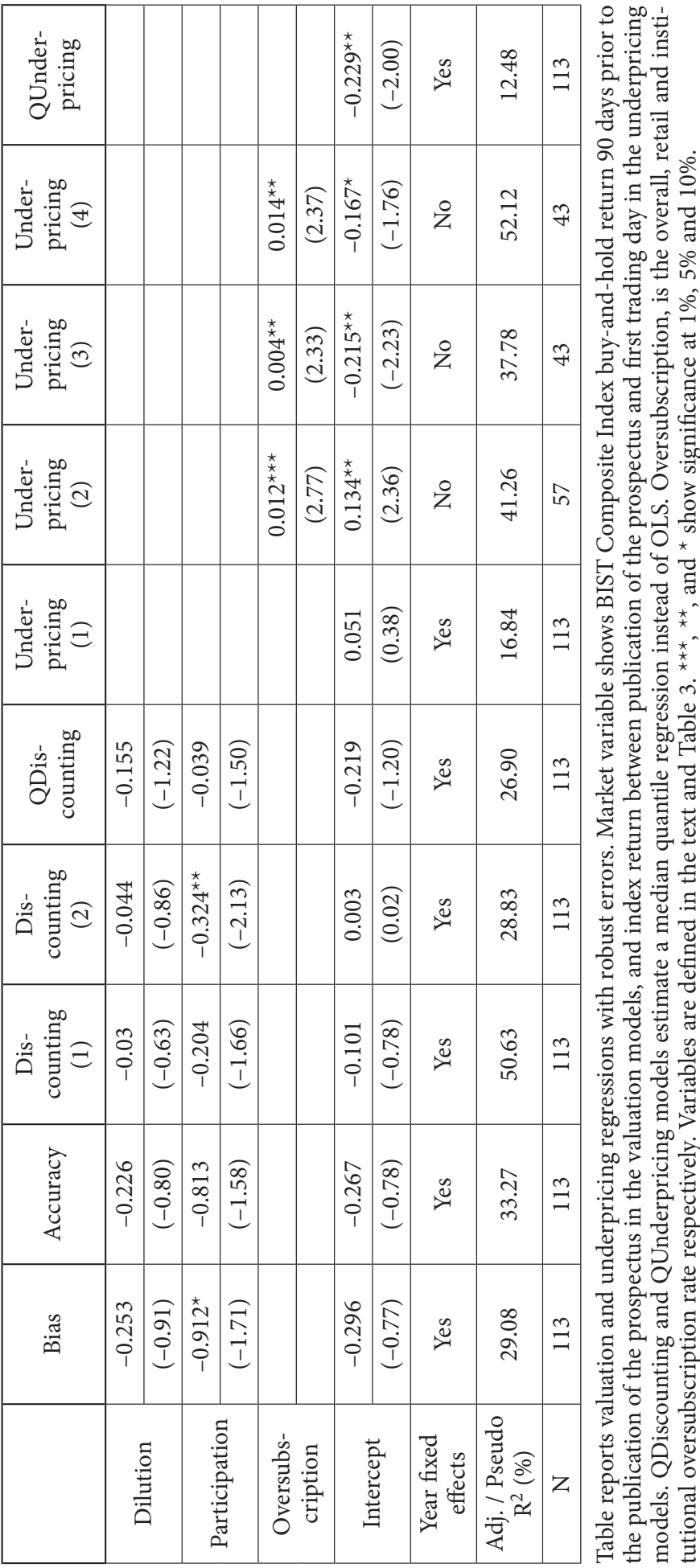


valuations. The third and fourth columns report discounting regressions with and without optimistic bias variable. In both constructs, bookbuilding is associated with larger discounts. The optimistic bias is highly significant, and its removal from the model leads to more than $20 \%$ reduction in the explained variation. One standard deviation increase in Optimism is associated with a $50.2 \%$ increase in DD, and one standard deviation increase in bookbuilding is associated with a $20.5 \%$ increase in discounts. The QDiscounting column reports parameters from the median quantile regression estimation. The signs of coefficients and their significance levels are in line with the OLS estimation. The underpricing regressions are reported in the last five columns. DD coefficient is significantly negative in all regressions. In the first model, one standard increase in DD is associated with a $30.4 \%$ reduction in market-adjusted initial returns. Notably, bookbuilding does not have a significant effect on the aftermarket returns. The next three columns show regressions with added oversubscription variable. Aggregate investor demand, retail and institutional investor demand are entirely positively related to initial returns. One standard deviation increase in aggregate oversubscription ratio is associated with a $34.5 \%$ increase in the initial returns. The last column reports the median quantile regression for underpricing. Consistent with the OLS estimates, the DD coefficient is negative and significant. $25^{\text {th }}$ and $75^{\text {th }}$ percentile regressions are also estimated for discounting and underpricing models. Their results are identical to the median quantile regressions and not reported here for reasons of brevity. Overall, pre-issue market return, deliberate discounts and intensity of investor demand are the main drivers of initial returns. The findings lend substantial support to H1 and H3, while H2 is rejected. The results are consistent with Chowdhry and Sherman's (1996a) mitigation of adverse selection through large retail allocation, Derrien's (2005) optimistic retail investor sentiment, and Hundtofte and Torstila's (2018) valuation anchoring explanations to underpricing. On the contrary, results do not support that in Turkish IPOs; underwriters offer more discounts to prevent a winner's curse (Rock, 1986), book-built offers are more discounted and underpriced (Benveniste \& Spindt, 1989), deliberate discounts lead to underpricing (Benveniste \& Spindt, 1989; Shiller, 1990; Roosenboom, 2012), and retail investors are allocated more of the overpriced offerings (Aggarwal et al., 2002).

\section{Conclusions}

In this study, valuation of IPOs and underpricing is investigated in a sample of 113 Turkish firms utilizing data collected from pre- and post-issue filings. Building on the existing theoretical and empirical evidence on underpricing, the study hypothesizes a connection between IPO valuation and initial returns to test the web of relations between offer method, underwriter discounts, optimistic valuation, investor demand and initial returns. This study supplies additional evidence on the impact of pre-issue valuation decisions on the post-issue firm from an emerging market, where fixed price is the dominant method of offering and retail investor allocations are large. It argues that offered deliberate discounts would be associated with the valuation bias of underwriters, by which means they may induce underpricing or pre-emptively overprice the issues. The findings are supportive of this argument.

The findings clearly demonstrate that issuers are valued by multiple techniques; MM and DCF being the most preferred methods and together comprising $87.22 \%$ of the total 
IPO value estimates. The fair value estimate is discounted by a median of $21 \%$ to set the final offer price. Discounting; however, does not induce underpricing as initial returns are disproportionally smaller than discounts. Median raw initial returns are $0.8 \%$ and median market-adjusted initial returns are a slightly higher $1.45 \%$. Moreover, difference tests show that IPOs in the large DD quantile have lower initial returns and larger bias than IPOs in the low DD quantile. Book-built offerings are more biased and less accurately valued than fixed price offerings at MM and fair value estimates. They are accompanied by larger discounts; however, this does not translate into underpricing due to large valuation bias. Retail and institutional investors subscribe more to underpriced offerings and less to overpriced offerings, suggesting that they do not suffer from the winner's curse. Finally, DD is positively associated with underwriter optimism and negatively associated with underpricing in this market setting, indicating that discounts reflect the valuation bias rather than being a genuine attempt to generate positive returns for potential investors. The results are consistent with a market setting, in which winner's curse problem is mitigated through large retail allocations (Chowdhry \& Sherman, 1996a), and underwriters are enabled to simultaneously overvalue and underprice the offerings by means of optimistic investor sentiment (Derrien, 2005). The underpricing is; however, small, signalling that underwriter discounts are not designed to reward the investors.

The results have several implications for investors, regulators, investment banks and issuers. The regulatory change concerning the mandatory disclosure of the valuation methodology is an important step to reduce the information asymmetry between insiders and investors. However, issuers claim up to $46 \%$ price discount to attract investor attention, which often fails to materialize after the IPO is completed. In fact, the study shows that heavily discounted IPOs are more overpriced. The results caution investors against this marketing practice, and urge the regulator, issuers and underwriters to enforce a more transparent and prudential approach to valuation. More specific regulations on this matter would restrict insiders' ability to overvalue and advertise themselves by means of discounting, which in turn could yield fair values closer to the intrinsic value and contribute to the market efficiency. The regulation may determine an upper limit to underwriter discounts or incorporate them into the cost of capital used to discount estimated future cash flows. Second, investors subscribing to the book-built IPOs must be cautious to the fact that issuers attempt to give themselves a better bargaining position in the price negotiations by offering larger discounts relative to the fixed price offerings, a practice likely to yield low initial returns due to the larger optimistic bias associated with it. Third, insiders tend to withhold information about dividend policy. As a result, DDM is never used in the valuation contrary to its high utilization in the European IPOs. This study encourages issuers to disclose more of their long-term policies in the prospectus so that investors and underwriters can more accurately assess value of the firm.

This research has two key limitations. The first one concerns the small sample size and the scarce voluntary disclosure of issuing firms, which usually refrain from publishing post-issue statistics on investor demand, subscription and allocation. As a result, several investigations and regressions remain confined to even smaller samples which may not represent the entire market. The second limitation is a methodological one and concerns the measurement of valuation bias. The bias variable should ideally measure prediction error relative to the 
intrinsic value of the issuer, which could be proxied by the equilibrium market price. Since equilibrium price is not known, bias is measured relative to the short-term prices in this study. This relies on the assumption that market is efficient and correctly prices the issuer.

An interesting extension to this research could be to study whether overvalued IPOs engage in earnings management to appear conservatively priced. Existing studies focus on the underwriter side of the valuation and ignore the managerial side. Since a strong earnings record would enhance IPO valuation by earnings multiples and future earnings forecasts, it may augment valuation errors or mitigate peer selection bias. In addition, an extension to the emerging markets with extreme demand intensity would provide useful insights on underwriters' valuation and discounting preferences.

\section{Author contributions}

The named author Lokman Tutuncu is solely responsible for the entire work.

\section{Disclosure statement}

I don't have conflicting or competing interest with any party.

\section{References}

Aggarwal, R., Prabhala, N. R., \& Puri, M. (2002). Institutional allocation in initial public offerings: empirical evidence. Journal of Finance, 57(3), 1421-1442. https://doi.org/10.1111/1540-6261.00465

Alford, A. (1992). The effect of the set of comparable firms on the accuracy of the price-earnings valuation method. Journal of Accounting Research, 30(1), 94-108. https://dx.doi.org/10.2307/2491093

Allen, F., \& Faulhaber, G. R. (1989). Signaling by underpricing in the IPO market. Journal of Financial Economics, 23(2), 303-324. https://doi.org/10.1016/0304-405X(89)90060-3

Baker, M., \& Wurgler, J. (2000). The equity share in new issues and aggregate stock returns. Journal of Finance, 55(5), 2219-2257. https://doi.org/10.1111/0022-1082.00285

Benveniste, L. M., \& Busaba, W. M. (1997). Bookbuilding vs. fixed price: An analysis of competing strategies for marketing IPOs. Journal of Financial and Quantitative Analysis, 32(4), 383-403. https://doi.org/10.2307/2331230

Benveniste, L. M., \& Spindt, P. A. (1989). How investment bankers determine price and allocation of initial public offerings. Journal of Financial Economics, 24(2), 343-361. https://doi.org/10.1016/0304-405X(89)90051-2

Bildik, R., \& Yilmaz, M. K. (2008). The market performance of initial public offerings in the Istanbul Stock Exchange. Journal of BRSA Banking and Financial Markets, 2(2), 49-76.

Bonaventura, M., \& Giudici, G. (2017). IPO valuation and profitability expectations: Evidence from the Italian exchange. Eurasian Business Review, 7(2), 247-266. https://doi.org/10.1007/s40821-016-0049-1

Bonaventura, M., Giudici, G., \& Vismara, S. (2018). Valuation and performance of reallocated IPO shares. Journal of Financial Markets, Institutions and Money, 54, 15-26. https://doi.org/10.1016/j.intfin.2017.05.005

Bradley, D. J., Jordan, B. D., \& Ritter, J. R. (2003). The quiet period goes out with a bang. Journal of Finance, 58(1), 1-36. https://doi.org/10.1111/1540-6261.00517 
Chahine, S. (2004). Long-run abnormal returns after IPOs and optimistic analysts' forecasts. International Review of Financial Analysis, 13(1), 83-103. https://doi.org/10.1016/j.irfa.2004.01.004

Chen, Y., Goyal, A., Veeraraghavan, M., \& Zolotoy, L. (2019). Media coverage and IPO pricing around the world. Journal of Financial and Quantitative Analysis (In press). https://doi.org/10.1017/S0022109019000486

Chowdhry, B., \& Sherman, A. (1996a). The winner's curse and international methods of allocating initial public offerings. Pacific-Basin Finance Journal, 4(1), 15-30. https://doi.org/10.1016/0927-538X(96)00004-2

Chowdhry, B., \& Sherman, A. (1996b). International differences in oversubscription and underpricing of IPOs. Journal of Corporate Finance, 2(4), 359-381. https://doi.org/10.1016/0929-1199(96)00002-8

Clarke, J., Khurshed, A., Pande, A., \& Singh, A. K. (2016). Sentiment traders and initial returns: The Indian evidence. Journal of Corporate Finance, 37, 24-37. https://doi.org/10.1016/j.jcorpfin.2015.10.007

Colaco, H. M. J., De Cesari, A., \& Hegde, S. P. (2017). Retail investor attention and IPO valuation. European Financial Management, 23(4), 691-727. https://doi.org/10.1111/eufm.12113

Deloof, M., Maeseneire, W. D., \& Inghelbrecht, K. (2009). How do investment banks value initial public offerings (IPOs)? Journal of Business Finance \& Accounting, 36(1-2), 130-160. https://doi.org/10.1111/j.1468-5957.2008.02117.x

Derrien, F. (2005). IPO pricing in "hot" market conditions: who leaves money on the table? Journal of Finance, 60(1), 487-521. https://doi.org/10.1111/j.1540-6261.2005.00736.x

Derrien, F., \& Womack, K. L. (2003). Auctions versus bookbuilding and the control of underpricing in hot IPO markets. Review of Financial Studies, 16(1), 31-61. https://doi.org/10.1093/rfs/16.1.0031

Durukan, M. B. (2002). The relationship between IPO returns and factors influencing IPO performance: case of the Istanbul Stock Exchange. Managerial Finance, 28(2), 18-38. https://doi.org/10.1108/03074350210767672

Firth, M., Li, Y., \& Wang, S. S. (2008). Valuing IPOs using price-earnings multiples disclosed by IPO firms in an emerging capital market. Review of Pacific Basin Financial Markets and Policies, 11(3), 429-463. https://doi.org/10.1142/S0219091508001428

Francis, J., Olsson, P., \& Oswald, D. R. (2000). Comparing the accuracy and explainability of dividend, free cash flow and abnormal earnings equity value estimates. Journal of Accounting Research, 38(1), 45-70. https://doi.org/10.2307/2672922

Gajewski, J. F., \& Gresse, C. (2006). A survey of the European IPO market (ECMI Paper).

Haggard, K. S., \& Xi, Y. (2017). IPO overvaluation and returns prior to lockup expiration. Managerial Finance, 43(12), 1392-1410. https://doi.org/10.1108/MF-05-2017-0172

How, J., Lam, J., \& Yeo, J. (2007). The use of comparable firm approach in valuing Australian IPOs. International Review of Financial Analysis, 16(2), 99-115. https://doi.org/10.1016/j.irfa.2006.09.003

Hsu, Y., Hung, C., \& Shiu, C. (2009). Why have IPO auctions lost market share to fixed-price offers? Evidence from Taiwan. Journal of Financial Studies, 17(1), 1-36. https://doi.org/10.6545/JFS.2009.17(3).1

Huang, H., Chiang, M., Lin, J., \& Lin, Y. (2017). Fixed-price, auction, and bookbuilding IPOs: Empirical evidence in Taiwan. Finance Research Letters, 22, 11-19. https://doi.org/10.1016/j.frl.2017.04.002

Hundtofte, C. S., \& Torstila, S. (2018). Evidence on anchoring to industry multiples in IPO pricing (Working paper). https://doi.org/10.2139/ssrn.2690869

Jenkinson, T., \& Jones, H. (2004). Bids and allocations in European IPO bookbuilding. Journal of Finance, 59(5), 2309-2338. https://doi.org/10.1111/j.1540-6261.2004.00700.x

Kim, M., \& Ritter, J. R. (1999). Valuing IPOs. Journal of Financial Economics, 53(3), 409-437. https://doi.org/10.1016/S0304-405X(99)00027-6 
Kiymaz, H. (2000). The initial and aftermarket performance of IPOs in an emerging market: evidence from Istanbul Stock Exchange. Journal of Multinational Financial Management, 10(2), 213-227. https://doi.org/10.1016/S1042-444X(99)00027-4

Ljungqvist, A., Nanda, V., \& Singh, R. (2006). Hot markets, investor sentiment, and IPO pricing. Journal of Business, 79(4), 1667-1702. https://doi.org/10.1086/503644

Lopez, A. R., \& Martin, G. R. (2019). The marketability discount in Spanish valuation multiples: Investors' perception in listed companies versus private transactions. Journal of Business Economics and Management, 20(1), 107-130. https://doi.org/10.3846/jbem.2019.8101

Loughran, T., Ritter, J. R., \& Rydqvist, K. (1994). Initial public offerings: international insights. PacificBasin Finance Journal, 2(2-3), 165-199. https://doi.org/10.1016/0927-538X(94)90016-7

Low, S., \& Yong, O. (2011). Explaining over-subscription in fixed-price IPOs: Evidence from the Malaysian stock market. Emerging Markets Review, 12(3), 205-216. https://doi.org/10.1016/j.ememar.2011.03.003

Paleari, S., \& Vismara, S. (2007). Over-optimism when pricing IPOs. Managerial Finance, 33(6), 352367. https://doi.org/10.1108/03074350710748722

Paleari, S., Signori, A., \& Vismara, S. (2014). How do underwriters select peers when valuing IPOs? Financial Management, 43(4), 731-755. https://doi.org/10.1111/fima.12060

Pandey, A. (2004). Initial returns, long run performance and characteristics of issuers: Differences in Indian IPOs following fixed price and book building processes (Working Paper). Indian Institute of Management, Ahmedabad.

Purnanandam, A. K., \& Swaminathan, B. (2004). Are IPOs really underpriced? Review of Financial Studies, 17(3), 811-848. https://doi.org/10.1093/rfs/hhg055

Ritter, J. R. (2003). Differences between European and American IPO markets. European Financial Management, 9(4), 421-434. https://doi.org/10.1111/1468-036X.00230

Ritter, J. R., \& Welch, I. (2002). A review of IPO activity, pricing and allocations. Journal of Finance, 57(4), 1795-1828. https://doi.org/10.1111/1540-6261.00478

Rock, K. (1986). Why new issues are underpriced. Journal of Financial Economics, 15(1-2), 187-212. https://doi.org/10.1016/0304-405X(86)90054-1

Roosenboom, P. (2007). How do underwriters value IPOs? An empirical analysis of the French IPO market. Contemporary Accounting Research, 24(4), 1217-1243. https://doi.org/10.1506/car.24.4.7

Roosenboom, P. (2012). Valuing and pricing of IPOs. Journal of Banking and Finance, 36(6), 1653-1664. https://doi.org/10.1016/j.jbankfin.2012.01.009

Sherman, A. (2005). Global trends in IPO methods: Bookbuilding versus auctions with endogenous entry. Journal of Financial Economics, 78(3), 615-649. https://doi.org/10.1016/j.jineco.2004.09.005

Shiller, R. J. (1990). Speculative prices and popular models. Journal of Economic Perspectives, 4(2), 55-65. https://doi.org/10.1257/jep.4.2.55

SPK. (2013a). Directive 128.VII.1 of the Capital Markets Board of 22 June 2013 on the Equity Issue. http://www.resmigazete.gov.tr/eskiler/2013/06/20130622-8.htm

SPK. (2013b). Bulletin 2013/5 of the Capital Markets Board of 12 February 2013 on the Equity Issue. http://spk.gov.tr/Bulten/Goster?year=2013\&no=5

Tinic, S. M. (1988). Anatomy of initial public offerings of common stock. Journal of Finance, 43(4), 789-822. https://doi.org/10.1111/j.1540-6261.1988.tb02606.x

Vismara, S., Signori, A., \& Paleari, S. (2015). Changes in underwriters' selection of comparable firms pre- and post-IPO: Same bank, same company, different peers. Journal of Corporate Finance, 34, 235-250. https://doi.org/10.1016/j.jcorpfin.2015.07.010

Welch, I. (1992). Sequential sales, learning, and cascades. Journal of Finance, 47(2), 695-732. https://doi.org/10.2307/2329120 